\title{
PENENTUAN NILAI PREMI ASURANSI PERTANIAN PADA KOMODITAS KOPI BERBASIS HARGA INTERNASIONAL MENGGUNAKAN MODEL MEAN REVERSION DENGAN LOMPATAN
}

\author{
Intan Lestari1§, Komang Dharmawan², Desak Putu Eka Nilakusmawati ${ }^{3}$ \\ ${ }^{1}$ Jurusan Matematika, FMIPA - Universitas Udayana [Email: intanlestari666@ gmail.com] \\ ${ }^{2}$ Jurusan Matematika, FMIPA - Universitas Udayana [Email: k.dharmawan@ @mail.com] \\ ${ }^{3}$ Jurusan Matematika, FMIPA - Universitas Udayana [Email: nilakusmawati@unud.ac.id] \\ $\S$ Corresponding Author
}

\begin{abstract}
Agricultural insurance with the interantional price is new insurance in Indonesia. The international insurance premium is given if the international prices lower than the determined trigger value. The purpose of this study is to presents the steps needed to determine the premium value of the agricultural insurance. The steps are to search data of the international prices and local prices commodity coffee, calculate the return of both data, calculate descriptive statistic, calculate correlation between international prices of commodity coffee and local prices commodity coffee, estimate the parameter by using Maksimum Likelihood Estimasi(MLE), to do the Monte Carlo simulation by using Mean Reversion with Jump Diffusion, to determine the production cost, normality log test, to determine the trigger indexs, and to count the premium value with put cash-or-nothing option. On this study if international prices lower than the determined trigger value, trigger payments as much as $\mathrm{Rp} 20.248 .282,4 / \mathrm{Ha}$ based on trigger index as many $\mathrm{Rp} 24.900 / \mathrm{kg}$, so amount of premium payment equals $\mathrm{Rp} 334.000$.
\end{abstract}

Keywords: Agricultural Insurance, International commodity coffee price, Mean Reversion with Jump Diffusion, Put Cash-or-Nothing Option

\section{PENDAHULUAN}

Di Indonesia komoditas kopi menjadi salah satu komoditas ekspor ungggulan di dunia yang telah berhasil meraih peringkat ketiga setelah Brazil dan Vietnam. Pada periode 1980-2013 neraca perdagangan kopi Indonesia mengalami surplus. Gejolak harga yang dialami oleh komoditas kopi berpengaruh terhadap harga pada tingkat produsen (petani). Hal ini berdampak bagi petani kopi berupa risiko ancaman kerugian saat gagal panen. Menurut Zorilla (2002) risiko usaha tani dipengaruhi oleh faktor iklim, faktor sanitasi, faktor geologi, faktor pasar dan faktor risiko yang dibuat oleh manusia itu sendiri. Faktor pasar tersebut berpengaruh terhadap risiko harga yang dikarenakan oleh harga komoditas kopi ditentukan oleh harga internasional yang fluktuasinya dipengaruhi oleh supply dan demand dari negara-negara produsen kopi dunia. Selain itu fluktuasi harga juga mengandung unsur risiko jika harga internasional mengalami lompatan. Lompatan adalah suatu kejadian saat harga pasar tiba-tiba melonjak naik atau anjlok dalam rentang waktu yang singkat (Tankov, 2008). Menurut Sedana et al. (2016) model Mean Reversion menyatakan bahwa harga akan cenderung kembali ketingkat nilai rata-rata. Jika harga naik atau menurun, yang artinya menjauh dari nilai rata-rata, maka pada saatnya nanti akan berbalik arah, kembali ke tingkat rata-rata. Sehingga penulis menggunakan model Mean Reversion dengan lompatan untuk melihat lompatannya.

Menurut Dharmawan et al., (2016) Asuransi diberikan pada usaha tani untuk 
melindungi petani dari risiko penurunan harga di pasar, khususnya untuk komoditas pertanian yang dijual di pasar modal seperti kopi, kedelai, kelapa sawit, cengkeh, dan lainnya. Undang-Undang Nomor 19 Tahun 2013 tentang Perlindungan dan Pemberdayaan Petani Pasal 30 ayat (1), "Pemerintah dan Pemerintah Daerah sesuai dengan kewenangannya berkewajiban melindungi usaha tani yang dilakukan oleh petani dalam bentuk asuransi pertanian".

Salah satu tantangan yang sering dihadapi oleh praktisi maupun peneliti dalam menentukan nilai premi asuransi pertanian ialah mendapatkan nilai premi yang adil bagi petani (tertanggung). Untuk mengetahui besarnya nilai premi yang harus dibayarkan oleh tertanggung, pada penelitian ini nilai opsi put tipe cash-ornothing digunakan sebagai penentu nilai premi karena memberikan hak untuk menjual produksi pertanian yang dimiliki oleh petani itu sendiri.

Menurut Wardhani dan Insafiah (2014) Asuransi pertanian berbasis harga internasional merupakan asuransi parametrik yaitu jenis asuransi dimana penanggung akan memberikan ganti rugi kepada tertanggung apabila terjadi peristiwa pemicu (trigger) yang telah disepakati antara kedua belah pihak dalam polis. Dalam hal ini pihak tertanggung akan memperoleh pertanggungan jika harga internasional jatuh dibawah nilai trigger yang ditentukan.

Berdasarkan latar belakang yang telah diuraikan diatas, maka penulis tertarik untuk menentukan nilai premi asuransi pertanian pada komoditas kopi berbasis harga internasional menggunakan model Mean Reversion dengan lompatan.

Menurut Dharmawan et al. (2016) opsi merupakan suatu kontrak atau perjanjian yang memberikan hak bukan kewajiban kepada pemegang kontrak untuk membeli atau menjual suatu asset induk (underlying asset) dengan indeks yang telah disepakati pada saat atau sebelum jatuh tempo (expiration date). Perhitungan premi asuransi pertanian yang menggunakan kontrak opsi berkaitan dengan istilah opsi put cash-or-nothing. Pemilik kontrak opsi put cash-or-nothing akan menerima sejumlah $\gamma$ rupiah saat kontrak jatuh tempo saat nilai $S_{t}<\mathrm{K}$, atau akan menerima 0 rupiah (tidak menerima apapun) saat $S_{t} \geq K$. Pada opsi put cash-or-nothing fungsi payoff atau reward dari kontrak opsi yang didefinisikan dalam persamaan berikut:

$$
\gamma=e^{-r(T-t)} \max \left(K-S_{t}, 0\right)
$$

dimana $S_{t}$ adalah harga komoditas pada waktu ke-t, $\mathrm{K}$ adalah trigger, $\mathrm{r}$ adalah suku bunga majemuk pada interval (T-t).

Nilai trigger pada penelitian ini dihitung berdasarkan hasil simulasi harga internasional bulanan komoditas kopi selama satu tahun. Misalkan pembayaran sekaligus dari kontrak asuransi pertanian adalah $\mathrm{P}$, maka nilai premi asuransi pertanian berbasis harga internasional dapat dihitung dengan formula:

$$
\text { Premi }=e^{-r(T-t)} N\left(-d_{2}\right)
$$

Simulasi harga komoditas kopi pada model mean reversion dengan lompatan dimisalkan sebagai:

$$
S_{t}=e^{X_{t}}
$$

(http://www.mathworks.com/help/fininst/simulat ing-electricity-prices-wirh-mean-reverting-andjump-diffusion.html):

dimana $S_{t}$ adalah harga pada waktu ke t. Logaritma dari harga dimodelkan dengan komponen $X_{t}$. Komponen stokastik dimodelkan sebagai proses Ornstein Uhlenbeck (mean reverting) dengan lompatan yaitu (Dixit and Pindyck, 1994.p.74):

$$
\begin{aligned}
\mathrm{d} X_{t}=\left(\alpha-\kappa X_{t}\right) d t & +\sigma d W_{t} \\
& +J\left(\mu_{j}, \sigma_{j}\right) d \Pi\left(\lambda_{t}\right)
\end{aligned}
$$

\section{METODE PENELITIAN}

Data yang digunakan dalam penelitian ini yaitu data harga internasional komoditas kopi yang tercatat pada Internasional Coffee Organization (ICO) periode Januari 2001 sampai Desember 2015 dan data harga lokal (tingkat produsen) komoditas kopi periode Januari 2004 sampai Desember 2015 diperoleh dari Dinas Perkebunan Provinsi Bali. Selain itu, biaya produksi kopi lokal (tingkat produsen) Kintamani terdiri dari biaya Prapanen yang 
diperoleh dari penelitian oleh Suarjana (2017), sementara biaya Pascapanen kopi Kintamani diperoleh dari Dinas Perkebunan Provinsi Bali. Nilai Kurs USD terhadap IDR, suku bunga, dan inflasi dikeluarkan oleh Bank Indonesia (BI). Langkah-langkah penelitian meliputi:

a. Mencari data harga internasional komoditas kopi pada International Coffee Organization (ICO) dan harga lokal (tingkat produsen) pada Dinas Perkebunan Provinsi Bali komoditas kopi

b. Menghitung tingkat pengembalian (return).

c. Menghitung nilai statistik deskriptif.

d. Menghitung korelasi harga internasional terhadap harga lokal komoditas kopi.

e. Mengestimasi parameter menggunakan metode Maksimum Likelihood Estimasi (MLE).

f. Melakukan simulasi Monte Carlo menggunakan model Mean Reversion dengan lompatan pada komoditas kopi berbasis harga internasional.

g. Menentukan total biaya Produksi (P) berdasarkan biaya Prapanen dan Pascapanen.

h. Melakukan uji lognormalitas data hasil simulasi.

i. Menentukan trigger $(\mathrm{K})$ yang didapat dari persentil data hasil simulasi.

j. Menghitung nilai premi asuransi pertanian menggunakan opsi put cash-or-nothing dengan nilai trigger yang berbeda-beda.

\section{HASIL DAN PEMBAHASAN}

\section{Data Historis Bulanan}

Data harga internasional komoditas kopi diperoleh dari International Coffee Organization (ICO) periode Januari 2001 sampai dengan Desember 2015 yang disajikan dalam bentuk plot harga dan plot log harga pada Gambar 1 .

Pada Gambar 1 dapat diamati plot harga dan plot log harga komoditas kopi internasional. Plot harga komoditas kopi internasional menunjukkan bahwa awal Tahun 2001 sampai Tahun 2011 dan Tahun 2014 sampai Tahun 2015 cenderung memiliki tren harga yang menaik. Tahun 2011 sampai Tahun 2014 harga komoditas kopi kembali mengalami penurunan atau harga cenderung menurun. Selain itu itu, plot log harga komoditas kopi internasional menunjukkan bahwa Tahun 2003 sampai Tahun 2011 dan Tahun 2014 sampai 2015 cenderung memiliki tren harga yang menaik. Sedangkan Plot log harga pada Tahun 2001 sampai Tahun 2003, Tahun 2011 sampai Tahun 2014 harga komoditas kopi kembali mengalami penurunan atau harga cenderung menurun. Dapat diamati pula pada Tahun 2001 sampai Tahun 2015 plot harga dan log harga cenderung memiliki data kenaikan ataupun penurunan harga pada tahun yang sama. Terlihat juga nilai data ekstrim dari data harga dan log harga komoditas kopi internasional selama Januari 2001 sampai Desember 2015.

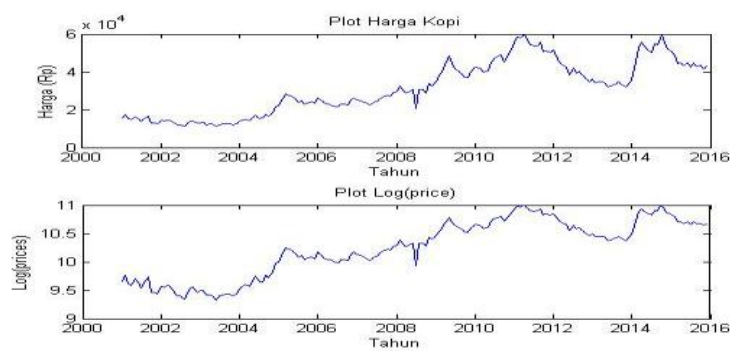

Gambar 1. Plot Harga dan Log Harga Internasional Komoditas Kopi Periode Januari 2001 sampai Desember 2015

\section{Menghitung Nilai Return}

Menentukan nilai return $\left(r_{t}\right)$ pada waktu $\mathrm{t}$ pada harga internasional bulanan komoditas kopi didapat digunakan persamaan berikut:

$$
r_{t}=\ln \left(\frac{S_{t+1}}{S_{t}}\right)
$$

maka diperoleh hasil yang tersaji pada Gambar 2. Pada Gambar 2. dapat diamati data lompatan atau data ekstrim dari harga komoditas kopi internasional periode Januari 2001 sampai Desember 2015 dengan data sebanyak 168 data bulanan. Pada Gambar 2 Garis Y1 merupakan batas atas terjadinya lompatan atau nilai data ekstrim bersifat positif, maka semua nilai return yang berada diatas garis Y1 merupakan lompatan atau data ekstrim. Begitu pula untuk garis Y2 merupakan batas bawah terjadinya 
lompatan atau nilai data ekstrim bersifat negatif. Maka semua nilai data return yang berada dibawah garis Y2 merupakan data lompatan atau data ekstrim

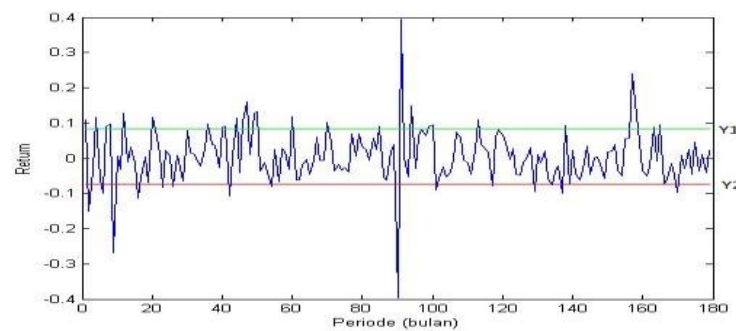

Gambar 2. Plot Return Harga Internasional Komoditas Kopi Periode Januari 2001 sampai Desember 2015

\section{Menentukan Nilai Mean, Variance, Skewness dan Kurtosis}

Nilai statistik deskriptif dicari dengan memanfaatkan data return harga internasional dan harga lokal komoditas kopi yang disajikan pada Tabel 1.

Tabel 1. Statistik Deskriptif

\begin{tabular}{|l|c|c|}
\hline \multirow{2}{*}{$\begin{array}{c}\text { Statistik } \\
\text { Deskriptif }\end{array}$} & \multicolumn{2}{c|}{ Komoditas Kopi } \\
\cline { 2 - 3 } & Internasional & Lokal \\
\hline Mean & 0,0056 & 0,0157 \\
\hline Varian & 0,0062 & 0,0147 \\
\hline Standar Deviasi & 0,0785 & 0,1214 \\
\hline Skwenes & $-0,0165$ & 1,7777 \\
\hline Kurtosis & 9,5291 & 9,9936 \\
\hline
\end{tabular}

Sumber: data diolah, 2017

Tabel 1 nilai statistik deskriptif harga internasional komoditas kopi dan komoditas kopi lokal jelas berbeda, dilihat dari nilai skwenes harga internasional bulanan komoditas kopi memiliki nilai sebesar $-0,0165$ (bernilai negatif) yang menandakan data harga komoditas kopi internasional mengalami kemencengan ke kiri. Sedangkan skwenes harga komoditas kopi lokal bernilai sebesar 1,777672 (bernilai positif) yang menandakan data harga komoditas kopi lokal mengalami kemencengan ke kanan. Kedua kurtosis harga komoditas kopi baik internasional maupun lokal bernilai lebih dari 3 yaitu berturutturut 9,5291 dan 9,993645 yang menandakan pada kedua data tersebut terdapat ekor gemuk (fat tail).

\section{Menghitung Korelasi Harga Internasional Terhadap Harga Lokal Komoditas Kopi}

Menentukan korelasi harga internasional terhadap harga lokal komoditas kopi periode Januari 2004 sampai Desember 2015 dapat dilakukan dengan menggunakan Metode Korelasi. Pengujian koefisien korelasi Pearson bertujuan untuk mengetahui keeratan hubungan antara variabel yang diirumuskan sebagai berikut:

$$
r_{x y}=\frac{n \sum x_{i} y_{i}-\left(\sum x_{i}\right) \cdot\left(\sum y_{i}\right)}{\sqrt{\left(n \sum x_{i}^{2} \cdot\left(x_{i}\right)^{2}\right) \cdot\left(n \sum y_{i}^{2} \cdot\left(y_{i}\right)^{2}\right)}}
$$

maka diperoleh hasil yang disajikan pada Tabel 2.

Tabel 2. Korelasi Harga Internasional Terhadap Harga Lokal Komoditas Kopi

\begin{tabular}{|c|c|c|}
\hline Bulan & Koefisien Korelasi & Interprestasi \\
\hline Januari & 0,5445 & Sedang \\
\hline Februari & 0,2231 & Rendah \\
\hline Maret & 0,4647 & Sedang \\
\hline April & 0,4560 & Sedang \\
\hline Mei & 0,3385 & Rendah \\
\hline Juni & 0,3343 & Rendah \\
\hline Juli & 0,5801 & Sedang \\
\hline Agustus & 0,7239 & Kuat \\
\hline September & 0,7915 & Kuat \\
\hline Oktober & 0,8122 & Sangat Kuat \\
\hline November & 0,8662 & Sangat Kuat \\
\hline Desember & 0,6413 & Kuat \\
\hline
\end{tabular}

Sumber: data diolah, 2017

Pada Tabel 2 dapat diamati hasil interprestasidari pengujian koefisien korelasi Pearson menurut pedoman oleh Sugiyono (2012). Dengan hasil yang menunjukkan derajat hubungan mulai dari sedang, kuat, sampai sangat kuat. Korelasi tertinggi terletak pada bulan November sebesar 0,8662 yang 
derajat hubungannya sangat kuat berada pada interval 0,80 sampai dengan 1,000.

\section{Estimasi Parameter Menggunakan MLE}

Untuk memperoleh hasil nilai parameter $\alpha$, $\phi, \mu_{j}, \sigma^{2}, \sigma_{j}^{2}, \lambda$ digunakan Maksimum Likelihood Estimasi (MLE) dengan bantuan program Matlab 2013 dengan diperoleh hasil yaitu $\widehat{\phi}=1-\kappa \Delta t=0,0868, \widehat{\sigma^{2}}=(0,2380)^{2}=$ $0,057, \widehat{\sigma_{J}^{2}}=(0,7995)^{2}=0,6392, \widehat{\lambda}=$ 0,3498 .

\section{Penentuan Biaya Produksi (P)}

Biaya produksi pada asuransi pertanian akibat harga internasional jatuh dibawah nilai trigger yang ditentukan berdasarkan data sekunder biaya Prapanen yang diperoleh dari penelitian oleh Suarjana (2017) sebesar Rp 15.222.813 yang berdasarkan luas lahan kopi Kintamani yang diolah sebesar 1,01 Hektar dengan hasil produksi mencapai 5,04 ton, sementara biaya Pascapanen kopi Kintamani diperoleh dari Dinas Perkebunan Provinsi Bali sebesar Rp 5.025.469,4 yang disesuaikan dengan inflasi tahun 2016 yaitu sebesar 3,53\%.

\section{Simulasi Monte Carlo Menggunakan Model Mean Reversion dengan Lompatan}

Simulasi Monte Carlo menggunakan model Mean Reversion dengan lompatan yaitu memperkirakan nilai harga internasional komoditas kopi pada waktu mendatang. Pada proses simulasi selama satu tahun dengan parameter yang digunakan diantaranya $\widehat{\phi}=$ $1-\kappa \Delta t=0,0868, \widehat{\sigma^{2}}=(0,2380)^{2}=$ $0,057, \widehat{\sigma_{J}^{2}}=(0,7995)^{2}=0,6392, \widehat{\lambda}=$

0,3498 dimasukkan ke dalam perintah program Matlab 2013 yang hasilnya berupa plot simulasi dan rataan simulasi harga internasional pada Gambar 3.

Berdasarkan Gambar 3 dapat dilihat plot simulasi dan plot rataan simulasi Monte Carlo menggunakan model Mean Reversion dengan lompatan. Plot simulasi dan plot rataan simulasi menunjukkan bahwa data hasil simulasi selama satu tahun terlihat beragam dan fluktuatif. Hasil simulasi kemudian dicari plot rataannya untuk memudahkan dalam mencari sebaran hasil simulasi. Dengan membandingkan plot simulasi dan plot rataan simulasi maka terlihat beberapa lompatan naik maupun turun pada beberapa hasil simulasi.
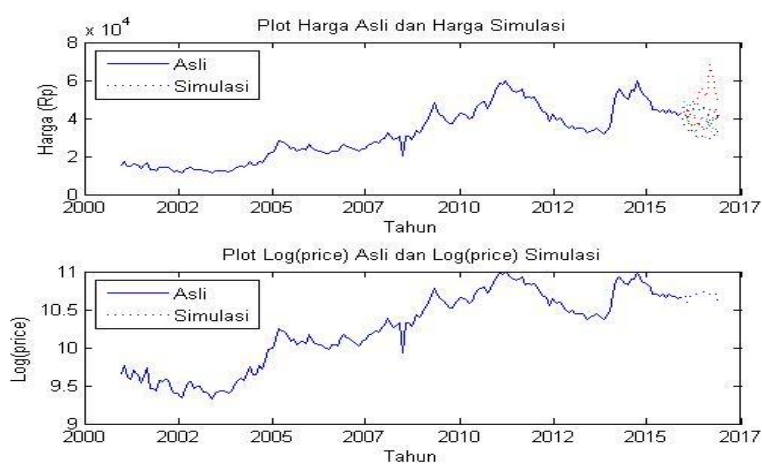

Gambar 3. Plot Simulasi dan Rataan Simulasi Harga Internasional Komoditas Kopi

\section{Uji Lognormalitas}

Uji lognormalitas digunakan untuk mengetahui populasi data berdistribusi lognormal atau tidak. Dalam penelitian ini menggunakan Uji Kolmogorov-Smirnov dengan menggunakan taraf signifikasi 0,05dengan Hipotesis yang diajukan adalah sebagai berikut :

$H_{0}$ : Data $\mathrm{X}$ berdistribusi lognormal

$H_{1}$ : Data $\mathrm{X}$ tidak berdistribusi lognormal

Tabel 3. Hasil Uji Lognormalitas dengan Kolmonogov-Smirnov.

\begin{tabular}{|c|c|c|}
\hline $\mathrm{N}$ & St-Dev & $p-$ value \\
\hline 100 & 15185 & 0,1308 \\
\hline
\end{tabular}

Tabel 3 memperlihatkan hasil uji lognormalitas menggunakan KolmonogovSmirnov untuk 100 kali simulasi harga internasional komoditas kopi dengan standar deviasi 15185 dan nilai $p$ - value sebesar 0,1308 . Karena nilai $p-$ value $>\alpha$ sehingga data yang diuji berdistribusi lognormal pada taraf signifikasi 0,05 .

\section{Penentuan Trigger (K)}

Penentuan trigger dilakukan dengan mencari persentil data hasil simulasi selama satu tahun. Persentil merupakan nilai yang membagi data menjadi seratus bagian sama besar. 


\section{Penentuan Nilai Premi Asuransi Pertanian}

Tahapan selanjutnya ialah menentuan nilai premi asuransi pertanian menggunakan opsi put cash-or-nothing. Implementasi perhitungan premi dengan penyesuaian diantaranya $C_{0}$ adalah harga yang diperoleh dari hasil simulasi Monte Carlo harga internasional komoditas kopi Mean Reversion dengan lompatan pada saat $\mathrm{t}=$ $0, C_{t}$ adalah nilai trigger $(\mathrm{K})$ diperoleh dari persentil data hasil simulasi komoditas kopi berbasis harga Internasional selama 1 tahun. Suku bunga bebas risiko pada penenlitian ini diasumsikan konstan $6,5 \%$ dan $\delta$ adalah deviden yang diasumsikan 0 .

Dalam penentuan nilai premi asuransi pertanian, dihitung untuk persentil 5 sampai dengan persentil 25 disajikan dalam Tabel 3. Sebagai contoh perhitungan yang dilakukan yaitu menghitung nilai premi asuransi pertanian untuk persentil 5 diperoleh sebagai berikut:

$$
\begin{aligned}
\text { Premi } & =20.248 .282,4 \cdot e^{-r T} \cdot N\left(-d_{2}\right) \\
& =20.248 .282,4 \cdot e^{-0,065 x 1} \cdot 0,01796 \\
& =334.000
\end{aligned}
$$

perhitungan $d_{2}$ diperoleh:

$$
\begin{aligned}
d_{2} & =\frac{\left(\frac{C_{0}}{C_{T}}\right)+\left(r-\frac{\sigma^{2}}{2}\right)(T-t)}{\sigma \sqrt{T-t}} \\
& =\frac{\ln \left(\frac{42.728}{24.900}\right)+\left(0,065-\frac{(0,2713)^{2}}{2}\right) \cdot 1}{0,2713 \cdot \sqrt{1}} \\
& =2.0942 \\
& =2.1 \text { (dibulatkan) }
\end{aligned}
$$

Tabel 4. Nilai Premi Untuk Trigger yang Berbeda-beda

\begin{tabular}{|c|c|c|c|c|}
\hline $\begin{array}{c}\text { Persen } \\
\text { til }\end{array}$ & $\begin{array}{c}\text { Trigger } \\
(\mathrm{Rp} / \mathrm{kg})\end{array}$ & $\begin{array}{c}\text { Produksi } \\
(\mathrm{Rp} / \mathrm{Ha})\end{array}$ & $\begin{array}{c}\text { Premi } \\
(\mathrm{Rp})\end{array}$ & $\%$ \\
\hline 5 & 24.900 & $20.248 .282,4$ & 344.000 & 1,64 \\
\hline 10 & 26.660 & $20.248 .282,4$ & 620.000 & 3,1 \\
\hline 15 & 29.000 & $20.248 .282,4$ & 1.189 .000 & 5,9 \\
\hline 20 & 30.260 & $20.248 .282,4$ & 1.603 .000 & 7,9 \\
\hline 25 & 31.680 & $20.248 .282,4$ & 2.160 .000 & 10,7 \\
\hline
\end{tabular}

Tabel 4 menunjukan hasil perhitungan premi asuransi pertanian pada komoditas kopi berbasis harga internasional berdasarkan nilai trigger yang berbeda-beda. Dalam Penelitian ini ditawarkan lima pilihamn premi asuransi. Ketika harga internasional jatuh dibawah nilai trigger yang ditentukan. Pembayaran sebesar Rp20.248.28,.4/Ha dengan berpatokan pada triggersebesar Rp. $24.900 / \mathrm{kg}$ maka premi yang harus dibayarkan sebesar Rp344.000. Tabel 4 juga menunjukkan semakin besar nilai trigger maka semakin besar nilai premi yang harus dibayarkan.

Jika dibandingkan dengan penelitian yang dilakukan oleh Suarjana 2017, harga premi yang jatuh pada persentil 5 sampai persentil 25 bernilai lebih besar dikarenakan pada penelitian ini digunakan simulasi Monte Carlo menggunakan model Mean Reversion dengan lompatan untuk mensimulasi harga komoditas kopi internasional pada waktu mendatang sesuai dengan periode yang ditentukan.

\section{KESIMPULAN DAN SARAN}

\section{Kesimpulan}

Model Mean Reversion dengan lompatan dapat dipakai untuk menentukan nilai premi asuransi pertanian pada komoditas kopi berbasis harga internasional dengan langkah awal yaitu mencari data harga internasional bulanan dan harga lokal bulanan komoditas kopi, dilanjutkan dengan menghitung return harga internasional dan harga lokal bulanan komoditas kopi, menghitung nilai masukan statistik deskriptif, menghitung korelasi harga internasional komoditas kopi terhadap harga lokal, , memplot masing-masing data, mengestimasi parameter, menentukan simulasi Monte Carlo menggunakan Mean Reversion dengan lompatan, menentukan total biaya produksi $(\mathrm{P})$, menentukan uji lognormalitas, menentukan trigger $(\mathrm{K})$ menggunakan persentil data hasil simulasi selama 1 tahun, dan langkah terakhir ialah menentukan nilai premi asuransi pertanian pada komoditas kopi berbasis harga internasional menggunakan opsi put cash-ornothing untuk nilai trigger yang berbeda-beda. 
Perubahan harga internasional pada komoditas kopi berpengaruh terhadap harga lokal (tingkat produsen) yang ditunjukkan dari korelasi yang tinggi pada bulan November sebesar 0,8662. Tinggi ataupun rendahnya korelasi dipengaruhi oleh supply dan demand serta pasokan komoditas kopi di pasar internasional yang berfluktuasi.

Hasil perhitungan premi asuransi pertanian pada komoditas kopi berbasis harga internasional diperoleh besaran premi dengan nilai trigger yang berbeda-beda. Dalam Penelitian ini ditawarkan lima pilihamn premi asuransi.

Jika dibandingkan dengan penelitian yang dilakukan oleh Suarjana 2017, harga premi yang jatuh pada persentil 5 sampai persentil 25 bernilai lebih besar dikarenakan pada penelitian ini digunakan simulasi Monte Carlo menggunakan model Mean Reversion dengan lompatan untuk mensimulasi harga komoditas kopi internasional pada waktu mendatang sesuai dengan periode yang ditentukan.

\section{Saran}

Dalam penelitian ini masih belum sempurna sehingga penulis menyarankan pada penelitian berikutnya untuk menentukan nilai premi asuransi pertanian pada komoditaskopi berbasis harga internasional menggunakan model Mean Reversion dengan lompatan perlu diikutsertakan suku bunga yang tidak konstan dan komoditas yang dipilih memiliki pola musiman.

\section{DAFTAR PUSTAKA}

Dharmawan, K., Widia, I W. dan Eswaryanti L.P.K.Y. 2016. Penerapan Metode Penilaian Kontrak Opsi dalam Penentuan Premi Asuransi Pertanian Berbasis Indeks Curah Hujan. Makalah Invited Speaker Pada Seminar Nasional Matematika XVIII Pekanbaru, Riau, 2-3 November 2016.

Dixit and Pindyck. 1994. Investement under Uncertainly. : Princeton University Press, 41 William Street, Princeton, New Jersey 08540 .

Sedana, Wirya., Dharmawan, $\mathrm{K}$ dan Asih, N. M., 2016. Penentuan Harga Kontrak
Berjangka Komoditas Kedelai Menggunakan Model Mean Reversion. EJurnal Matematika Vol. 5 (4), November pp. 170-175.

Simulating Electricity Prices with Mean Reverting and Jump Difussion. (http://www.mathworks.com/help/fininst/si mulating-electricity-prices-wirh-meanreverting-and-jump-diffusion.html).

Suarjana, I.W., Widia, I.W dan Dharmawan, K., 2017. Penentuan Nilai Kontrak Asuransi Usaha Tani Tanaman Kopi Arabika Berbasis Indeks Harga Internasional. Jurnal Beta (Biosistem dan Teknik Pertanian) Vol.5. no.2, pp.1-8

Sugiyono. 2012. Metode Penelitian Kuantitatif Kualitatif dan R\&D. Penerbit Alfabeta. Bandung.

Tankov, P. 2003. Financial Modelling with Jump Processes CRC Press.

Undang-undang Republik Indonesia No. 19 Tahun 2013 Tentang Perlindungan dan Pemberdayaan Petani.

Wardhani, I dan Insafiah. 2014. Kajian Persiapan Implementasi Asuransi Pertanian Secara Nasional.Jakarta: Kementerian Keuangan Republik Indonesia Badan Kebijakan Fisikal Pusat Pengelolaan Risiko Fisikal.

Zorilla, Jose Luis. 2002. "Ekstensive Herbaceous Cultivation and Cattle Risk: Possibilites that Agricultural Insurance Offers for their Management." International Conference: Agricultural and Income Guarantee. Madrid. 